\title{
RNH1 Gene
}

National Cancer Institute

\section{Source}

National Cancer Institute. RNH1 Gene. NCI Thesaurus. Code C101602.

This gene plays a role in enzyme inhibition. 